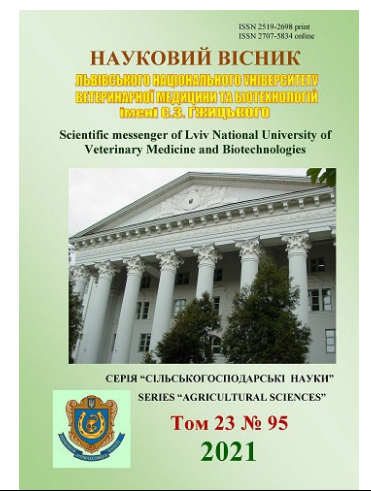

Науковий вісник Дьвівського національного університету ветеринарної медицини та біотехнодогій імені С.3. Гжицького. Серія: Сільськогосподарські науки

\author{
Scientific Messenger of Lviv National University \\ of Veterinary Medicine and Biotechnologies. \\ Series: Agricultural sciences
}

ISSN 2519-2698 print ISSN 2707-5834 online doi: 10.32718/nvlvet-a9505

https://nvlvet.com.ua/index.php/agriculture

UDC 619:614.31:618.19-002-07:636.2

\title{
Bacteriological control of milk and effectiveness of antimastitis measures in cows
}

\author{
T. A. Velesyk ${ }^{1}$, N. P. Boltyk ${ }^{2}$, R. M. Sachuk ${ }^{1}$, Ya. S. Stravsky ${ }^{3}$, O. A. Katsaraba ${ }^{4}$, S. A. Ponomareva ${ }^{5}$, \\ O. M. Pinchuk ${ }^{1}$ \\ ${ }^{1}$ Rivne State University for the Humanities, Rivne, Ukraine \\ ${ }^{2}$ Ternopil Research Station, Institute of Veterinary Medicine NAAN, Ternopil, Ukraine \\ ${ }^{3}$ I. Gorbachevsky Ternopil National Medical University, Ternopil, Ukraine \\ ${ }^{4}$ Stepan Gzhytskyi National University of Veterinary Medicine and Biotechnologies Lviv, Lviv, Ukraine \\ ${ }^{5}$ State Scientific-Research Control Institute for Veterinary Medicinal Products and Feed Additives, Lviv, Ukraine
}

Article info

Received 15.04.2021

Received in revised form 17.05.2021

Accepted 18.05.2021

Rivne State University for the Humanities, Plastova Str., 29-a Rivne, 33028, Ukraine. Tel.: +38-097-671-90-63

E-mail: sachuk.08@ukr.net

Ternopil Research Station, Institute of Veterinary Medicine, NAAN, Troleybusna Str., 12, Ternopil, 46027, Ukraine.

I. Gorbachevsky Ternopil National Medical University, Maidan Voli, 1 Ternopil, 46002, Ukraine.

Stepan Gzhytskyi National University of Veterinary Medicine and Biotechnologies Lviv, Pekarska Str., 50, Lviv, 79010 Ukraine.

State Scientific-Research Control Institute for Veterinary Medicinal Products and Feed Additives, Donetsk Str., 11, Lviv, 79000 Ukraine.

Velesyk, T. A., Boltyk, N. P., Sachuk, R. M., Stravsky, Ya. S., Katsaraba, O. A., Ponomareva, S. A., \& Pinchuk, O. M. (2021). Bacteriological control of milk and effectiveness of antimastitis measures in cows. Scientific Messenger of Lviv National University of Veterinary Medicine and Biotechnologies. Series: Agricultural sciences, 23(95), 38-44. doi: 10.32718/nvlvet-a9505

Under the current conditions of livestock development, the main task of farms is the systematic bacteriological control of milk and the development of comprehensive programs for the control and prevention of mastitis in cows. These measures will make it possible to establish control over this pathology, reduce veterinary treatment costs, improve milk quality, increase average hopes for lactation, increase the productive use of cows, and more. It was found that among the forms of clinical mastitis in the farm registered catarrhal and purulent-catarrhal $(65.0 \%)$, serous $(12.0 \%)$, and less often - fibrinous $(11.5 \%)$, hemorrhagic $(11.0 \%)$, and abscess udder $(0.5 \%)$. Bacteriological studies of milk taken from cows proved the presence of Staphylococcus saprophyticus, Escherichia coli, $\beta$-hemolytic Streptococcus spp. Microbiological studies showed that the isolated cultures of microorganisms were sensitive to tetracycline, neomycin, and cloxacycline; conditionally sensitive to streptomycin, doxycillin; no sensitivity to amoxicillin + clavulanic acid, norfloxacin and gatifloxacin. A treatment scheme was proposed for patients with purulent-catarrhal mastitis of cows, included intra-tank injections of the drug "Mastidev-Linko," intramuscular injections of the drug "Tseftiodev 5\%" and external application of the ointment "Dibutaliastin." As a result of studies on the therapeutic efficiency of the proposed veterinary drugs when used in cows of Holstein-Friesian and black-spotted breed, patients with purulent-catarrhal mastitis, $91.6 \%$ therapeutic efficiency of drugs was established. It is recommended that animals infected with infectious agents should be milked last and milking machines thoroughly disinfected; apply the pre-and post-milking treatment of udder teats with disinfectants (dips); periodically check in the laboratory the disinfecting ability of drugs for udder treatment and disinfection of accessories; use only proven tools; control the correct preparation of solutions and treatment of the udder with disinfectants (dips); to reject animals that do not respond to treatment (chronically ill). astin",

Key words: milk, microorganisms, mastitis, efficiency, "Mastidev-Linko”, “Tseftiodev 5\%”, “Dibutali-

\section{Бактеріологічний контроль молока корів та ефективність протимаститних заходів}

Т. А. Велесик ${ }^{1}$, Н. П. Болтик ${ }^{2}$ Р. М. Сачук ${ }^{1}$, Я. С. Стравський ${ }^{3}$, О. А. Кацараба ${ }^{4}$, С. А. Пономарьова О. М. Пінчук ${ }^{1}$

${ }^{1}$ Рівненський державний гуманітарний університет, м. Рівне, Украӥна

${ }^{2}$ Тернопільська дослідна станиія Інституту ветеринарної медицини НААН, м. Тернопіль, Україна

${ }^{3}$ Тернопільський національний медичний університет імені I. Я. Горбачевського, м. Тернопіль, Украӥна 
${ }^{4}$ Львівський національний університет ветеринарної медицини та біотехнологій імені С. 3. Гэсицького, м. Львів, Україна

${ }^{5}$ Державний науково-дослідний контрольний інститут ветеринарних препаратів та кормових добавок, м. Львів, Україна

При нинішніх умовах розвитку тваринництва, основним завданням господарств залишається систематичний бактеріологічний контроль молока та розробка комплексних програм боротьби й профілактики маститу корів. Дані заходи дадуть можливість встановити контроль над иією патологією, зменшити ветеринарні витрати на лікування, покрашити якість молока, підвищити середній надій за лактацію, збільшити термін продуктивного використання корів тощо. Встановлено, щцо серед форм клінічного маститу, у господарстві реєстрували: катаральний і гнійно-катаральний (65,0 \%), серозний (12,0\%), рідше - фібринозний (11,5\%), геморагічний (11,0\%) мастит та абсиес вимені (0,5\%). Бактеріологічними дослідженнями молока, відібраного від корів, доведена наявність Staphylococcus saprophyticus, Escherichia coli, $\beta$-гемолітичний Streptococcus spp. Miкробіологічними дослідженнями встановлено, щчо виділені культури мікроорганізмів були чутливими до тетрацикліну, неоміцину $і$ клоксацикліну; умовно чутливими до стрептоміцчину, доксициліну; відсутня чутливість до амоксищилін+клавуланової кислоти, норфлоксацину та гатифлоксацину. Запропоновано схему лікування, яка для хворих на гнійно-катаральний мастит корів, передбачала внутрішньочистернальні введення препарату “Мастидев-Лінко”, внутрішньом'язові ін'єкції лікарського засобу “Цефтіодев 5 \%” та зовнішнє застосування мазі “Дібуталястін”. У результаті проведених досліджень терапевтичної ефективності, запропонованих ветеринарних препаратів при застосуванні у корів голитинсько-фризької та чорно-рябої породи, хворих на гнійно-катаральний мастит, встановлено 91,6\% терапевтичну ефективність лікарських засобів. Господарству рекомендовано наступне: тварин, інфікованих заразними збудниками, слід доїти в останню чергу та ретельно дезінфікувати доїльні апарати; застосовувати перед- та післядоїльну обробку дійок вимені дезінфектантами (діпами); періодично перевіряти в лабораторії дезінфікуючу здатність препаратів для обробки вимені та дезінфекиї приладдя; використовувати тільки перевірені засоби для дезінфекції; контролювати правильність приготування розчинів та проведення обробки вимені дезінфектантами (діпами); вибраковувати тварин, які не піддаються лікуванню (хронічно хворих).

Ключові слова: молоко, мікроорганізми, мастит, ефективність, “Мастидев-Лінко”, “Цефтіодев 5 \%”, “Дібуталястін”.

Вступ

Молоко та молочні продукти відіграють надзвичайно важливу роль у харчовому ланцюзі людей будьякого віку. В коров'ячому молоці, крім основних компонентів (жир, білок, вуглеводи), міститься близько 150 поживних речовин (вітаміни, мікромакроелементи та ін.), які мають важливе значення для життєдіяльності людського організму. Поряд 3 тим, що молоко і молочні продукти необхідні для життєдіяльності людей, вони також $є$ сприятливим поживним середовищем для розвитку мікроорганізмів (Shkromada et al., 2019). Порушення ветеринарносанітарних норм утримання і технології доїння лежать в основі виникнення маститів, а відсутність своєчасної діагностики, ізоляції хворих тварин і їх лікування призводить до поширення захворювання. Усі мікроорганізми, що викликають мастити, можна розділити на дві основні категорії: збудники з зовнішнього середовища (екологічні) та контагіозні. Перші спостерігаються в оточенні корови: вони знаходяться в підстилці, тирсі, фекаліях чи брудній воді, що застоялася, а зараження найчастіше фіксується в період між доїннями. Найбільша частота захворювань спостерігається в період зниження імунітету, наприклад, після отелу. До збудників природного середовища відносяться Streptococcus uberis, Escherichia coli, Klebsiella spp., Pasteurella spp., Enterobacter spp., Serratia spp., Pseudomonas spp., Protheca spp. (Berezovskyi et al., 2018; Borodina \& Dmytro, 2018).

В процесі доїння має місце передача контагіозних патогенів. Ці організми, на відміну від описаних вище, добре пристосовані до розмноження в паренхімі вимені і мають специфічні біологічні пристосування до такого розмноження: тропізм до альвеолярних клітин (функціональних клітин вимені).

До контагіозних збудників відносять Staphylococcus aureus, Streptococcus agalactiae, Corynebacterium bovis, Trueperella pyogenes, Mycoplasma spp., при чому перші два - до списку провідних збудників маститу в молочному секторі світу. При порушенні санітарних умов отримання та зберігання, молоко може бути небезпечним джерелом вищевказаної інфекції (Paliy, 2017; Berezovskyi et al., 2018; Borodina \& Dmytro, 2018).

Невід'ємною ланкою програм подолання маститу є комплексні заходи, спрямовані на комплексну терапію із використанням системних антибіотиків.

Відповідно господарства, завдяки комплексним програмам боротьби та профілактики, зможуть встановити контроль над цією патологією, зменшити ветеринарні витрати на лікування, покращити якість молока, підвищити середній надій за лактацію, збільшити термін продуктивного використання корів тощо.

Аналіз останніх досліджень $i$ публікацій. Мастит посідає провідне місце у структурі запальних захворювань в акушерстві та $\epsilon$ основною причиною порушення репродуктивної функції корів (Saini et al., 2019; Singh et al, 2020; Kurtyak et al., 2021). Відомо, що пізня діагностика маститу у тварин, несвоєчасне та/або неадекватне лікування ускладнює їх перебіг і $є$ однією 3 найчастіших причин неплідності (Stefanyk et al., 2017; Mohammed et al., 2019; Roman et al., 2020). Дана патологія широко розповсюджена на молочних фермах усього світу та завдає значних економічних збитків унаслідок недоотримання 10-15 \% річного надою молока на корову за 3-4 лактації, зниження його якості, передчасного вибракування 30 \% тварин, недоотримання 2-3-ох телят, захворюваності новонароджених і витрат на лікування (Thomas et al, 2015; Jamali et al., 2018; Ruegg \& Petersson-Wolfe, 2018).

Не викликає сумніву, що головним завданням у лікуванні тварин, хворих на мастит, залишається ліквідація запального процесу з використанням антибіотикотерапії. Але антибактеріальна терапія, прописана у сучасних протоколах лікування корів, не завжди $є$ 
ефективною. Широкий розвиток полімікробної резистентності, зміна спектру мікроорганізмів вимені, продукція багатьма з них бета-лактамаз, створюють труднощі під час вибору антибактеріального препарату і роблять терапію малоефективною. У більшості випадків терапевтичного ефекту вдається досягти завдяки застосуванню препаратів нових класів. В основі втілення цього принципу лежить мікробіологічне обгрунтування вибору антибактеріального препарату.

Тому виходячи із вище викладеного, метою нашої роботи було провести бактеріологічний аналіз молока для визначення збудника і його чутливості до антибіотиків, вивчити терапевтичну ефективність препаратів при лікуванні корів, хворих на гнійно-катаральний мастит.

\section{Матеріал і методи досліджень}

Досліди проводились у ФГ “Мрія” с. Велика Омеляна Рівненського району Рівненської області на коровах чорно-рябої породи, які утримуються стійловопасовищною системою.

Діагностику маститу корів проводили за допомогою експрес-тесту, з використанням реактиву Profilac Reagent $\mathrm{N}$ для визначення вмісту соматичних клітин у сирому молоці. Облік реакції проводили через контроль утворення гелю та зміни кольору проби молока через зміну рН у лабораторії з контролю якості, безпечності та реєстрації ветеринарних лікарських засобів і кормових добавок ТОВ “ДЕВІЕ”.

Дослідження проводили на молочно-контрольних пластинках безпосередньо біля тварин. Для цього в кожну заглибину пластинки до контрольної лінії 3 відповідної долі вимені надоювали по $1 \mathrm{~cm}^{3}$ молока i додавали $1 \mathrm{~cm}^{3}$ розчину реактиву Profilac Reagent $\mathrm{N}_{3}$ пляшки піпеткою-автоматом. Молоко 3 реактивом протягом 10-15 с перемішували скляною паличкою. Під час обліку реакції враховували забарвлення суміші та утворення желеподібного згустку.

Результати тесту оцінювали за такими критеріями:

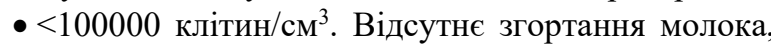
рідка консистенція. Зразки легко розливаються на невеликі порції;

• + 100000-300000 клітин/см³. Відмічається незначне згортання. Зразки можуть розливатись на порції;

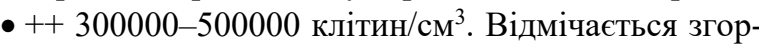
тання молока 3 утворенням невеликої кількості гелю. Важко розливати на порції;

- +++ 500000-1,5 млн клітин $/ \mathrm{cm}^{3}$. Згортання 3 утворенням гелю майже 3 усієї проби. Розливати на порції стає важчим;

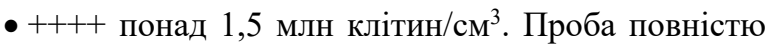
згорнулась 3 утворенням гелю. Розливання на порції неможливе.

Різні діапазони кількості соматичних клітин класифікуються за допомогою видимих змін кольору і консистенції зразків сирого молока. Тест реагує від 100 тис. соматичних клітин.

Відбір проб молока-сировини та доставку їх у лабораторію тваринництва, ветеринарного акушерства та санітарії (Свідоцтво про відповідність системи вимірювань ДСТУ ISO 10012:2005 № 02-0044/2021) Тернопільської дослідної станції ІВМ НААН проводили згідно з ДСТУ 4834:2007, ДСТУ IDF 122С:2003.

Клінічні мастити діагностували шляхом огляду вим’я, його пальпації та пробного доїння.

Для дослідження мікрофлори зразки молока висівали на поживні середовища. При цьому для виділення стафілококів використовували BD Baird-Parker Agar (HiMedia, Індія); коліформних бактерій - агар Ендо (Фармактив, Україна), ентерококів - Ентерокок агар (Фармактив, Україна). Культивування проводили за температури $37^{\circ} \mathrm{C}$, результати оцінювали через 24 48 годин. Ідентифікацію чистих культур проводили за морфологічними, тинкторіальними, культуральними, біохімічними властивостями, які описані у визначнику бактерій Берджі (Vos et al., 2011).

Чутливість ізолятів до антибактеріальних препаратів визначали диско-дифузійним методом, використовуючи диски 3 антибіотиками (Himedia, Індія). При постановці методу використовували Mueller Hinton Agar (Himedia, Індія). Приготування мікробних суспензій проводили відповідно до оптичного стандарту мутності 1,0 одиниць за шкалою McFarland з використанням приладу Densi-LaMeter (PLIVA-Lachema Diagnostika, Чехія).

Визначення чутливості мікроорганізмів до препаратів проводили наступним способом. Готували суспензії з чистих культур, висівали суспензії в чашки Петрі 3 відповідним середовищем, виготовляли в середовищі лунки за допомогою пробійника № 10, заповнювали їх експериментальними зразками лікарських засобів. Чашки Петрі інкубували в термостаті упродовж 24 годин, потім оцінювали результат за діаметром затримання росту мікроорганізмів навколо лунки. Результати оцінювали таким чином: діаметр до 15 мм - мікроорганізми нечутливі до антисептиків; від 16 до 20 мм - мікроорганізми помірно чутливі до антисептиків; від 21 до 25 мм - мікроорганізми чутливі до антисептиків; від 26 мм і більше - мікроорганізми високочутливі до антисептиків.

Для визначення ефективності схеми лікування гнійно-катарального маститу було відібрано дві групи корів (голштинсько-фризької та чорно-рябої породи, віком від 2 до 4 років, живою масою 450-600 кг) $(\mathrm{n}=12)$. Критерієм відбору була клінічна картина гнійно-катарального маститу у корів, виділена мікрофлора у молоці та чутливість мікроорганізмів до препаратів.

Молоко від хворих тварин у період лікування здоювали в окремий посуд і утилізували. У реалізацію молоко допускали після негативної діагностичної проби з реактивом Profi lac Reagent N.

Статистичну обробку результатів виконано за загальноприйнятою методикою (Rokytskyi, 1973).

\section{Результати та їх обговорення}

Під час акушерсько-гінекологічної диспансеризації корів з'ясували, що 49 \% поголів'я хворі на клінічні (28,0 \%) та субклінічні (21,0\%) мастити. Відмічалося значне поширення клінічного маститу в корів після отелення. Серед форм клінічного маститу у 
господарстві реєстрували катаральний і гнійнокатаральний $(65,0 \%)$, серозний $(12,0 \%)$, і рідше фібринозний $(11,5 \%)$, геморагічний $(11,0 \%)$ та абсцес вимені $(0,5 \%)$.

У хворих на гостру форму гнійно-катарального маститу корів відзначали зниження молочної продуктивності, збільшення в об'ємі вражених часток вимені. При пальпації такі частки були щільної консистенції, болючі, гарячі на дотик. Секрет з ураженої частки - водянистої консистенції, сіруватого або солом'яного кольору з домішками пластівців гною.
Умови утримання сухостійних корів не відповідали вимогам - недостатня площа на утримання, відсутність навісів надворі, тварини часто лягали на гнойовому проході.

Молоко від дев'яти хворих корів 3 кожної ураженої дійки піддавалося визначенню збудника i його чутливості до антибіотиків. У досліджуваних проб було встановлено наявність у молоці Staphylococcus saprophyticus, Escherichia coli, $\beta$-гемолітичний Streptococcus spp. (табл. 1).

\section{Таблиця 1}

Результати бактеріологічних досліджень зразків молока

\begin{tabular}{|c|c|c|c|c|}
\hline $\begin{array}{l}\text { Номер } \\
\text { зразку }\end{array}$ & Досліджуваний матеріал & Найменування показника & $\begin{array}{c}\text { Результат } \\
\text { дослідження }\end{array}$ & Методи дослідження \\
\hline 0101/МБ1 & $\begin{array}{l}\text { молоко від корови } \\
8015259901\end{array}$ & $\begin{array}{c}\text { Staphylococcus saprophyticus, } \\
\text { Escherichia coli }\end{array}$ & Виділено & \multirow{9}{*}{$\begin{array}{c}\text { Згідно ДСТУ 7357:2013 “Молоко } \\
\text { та молочні продукти. Методи } \\
\text { мікробіологічного контролюван- } \\
\text { ня”, ГОСТ 30347-97 “Молоко и } \\
\text { молочные продукты. Методы } \\
\text { определения Staphylococcus } \\
\text { aureus” }\end{array}$} \\
\hline 0101/МБ2 & $\begin{array}{c}\text { молоко від корови } \\
8014618241\end{array}$ & $\begin{array}{c}\beta \text {-гемолітичний } \\
\text { Streptococсиs spp. }\end{array}$ & Виділено & \\
\hline 0101/МБ3 & $\begin{array}{l}\text { молоко від корови } \\
8030610299\end{array}$ & Staphylococcus saprophyticus & Виділено & \\
\hline 0101/МБ4 & $\begin{array}{c}\text { молоко від корови } \\
8011270469\end{array}$ & $\begin{array}{c}\text { Staphylococcus saprophyticus, } \\
\text { Escherichia coli }\end{array}$ & Виділено & \\
\hline 0101/МБ5 & $\begin{array}{l}\text { молоко від корови } \\
8011270203\end{array}$ & $\begin{array}{c}\text { Staphylococcus saprophyticus, } \\
\text { Escherichia coli }\end{array}$ & Виділено & \\
\hline 0101/МБ6 & $\begin{array}{c}\text { молоко від корови } \\
8011270469\end{array}$ & $\begin{array}{c}\text { Staphylococcus saprophyticus, } \\
\text { Escherichia coli }\end{array}$ & Виділено & \\
\hline 0101/МБ7 & $\begin{array}{l}\text { молоко від корови } \\
8011270109\end{array}$ & $\begin{array}{c}\text { Staphylococcus saprophyticus, } \\
\text { Escherichia coli }\end{array}$ & Виділено & \\
\hline 0101/МБ8 & $\begin{array}{l}\text { молоко від корови } \\
8011270411\end{array}$ & $\begin{array}{c}\beta \text {-гемолітичний } \\
\text { Streptococcus spp. } \\
\text { Escherichia coli }\end{array}$ & Виділено & \\
\hline 0101/МБ9 & $\begin{array}{c}\text { молоко від корови } \\
8011270307\end{array}$ & $\begin{array}{c}\text { Staphylococcus saprophyticus, } \\
\text { Escherichia coli }\end{array}$ & Виділено & \\
\hline
\end{tabular}

Виділені бактерії відносяться до заразних збудників маститу (джерело походження - заражені тварини, невідповідність умов утримання) і передаються від тварини до тварини під час доїння - “Проблема доїльної зали".

Мікробіологічними дослідженнями встановлено, що виділені культури мікроорганізмів були чутливими до тетрацикліну, неоміцину і клоксацикліну; умовно чутливими до стрептоміцину, доксициліну; відсутня чутливість до амоксицилін+клавуланової кислоти, норфлоксацину та гатифлоксацину (табл. 2).

Враховуючи результати лабораторних досліджень, ми запропонували схему лікування, яка для хворих на гнійно-катаральний мастит корів (дослідна група) передбачала внутрішньоцистернальні введення препарату “Мастидев-Лінко”. До складу його входив: лінкоміцину гідрохлорид, сульфатіазолу натрію, триметоприму i преднізолон, у поєднанні з внутрішньом'язовими ін'єкціями “Цефтіодеву 5 \%”, до складу якого входив цефтіофуру гідрохлорид. Для зняття набряку і зменшення болі у вимені, застосовували мазь “Дібуталястін”. Мазь наносили тонким шаром на шкіру вимені два рази на добу до закінчення курсу лікування маститу.
Корів за гнійно-катарального маститу контрольної групи лікували за схемою, яка передбачала внутрішньоцистернальні введення препарату “Амоксицилін”, суспензія для інтрацистернального введення протягом 4-х діб. Здійснювали зовнішнє застосування мазі “Захисна форте" (анестезин, вітамін А, цинку оксид) - на уражену долю вимені, два рази на добу до закінчення лікування та ін'єкційне введення лікарського засобу "Біофлок", до складу якого входив енрофлоксацин $10 \%$. Для визначення терапевтичної ефективності застосування ветеринарних препаратів при лікуванні корів за клінічного маститу, враховували результати щоденного дослідження стосовно загального стану тварин, рухливості, апетиту. Особливу увагу звертали на стан вимені (можливі вогнища ущільнення, болючість, місцеву температуру), надвим'янних лімфатичних вузлів).

У результаті проведених досліджень було, встановлено наступне. Протягом експерименту у корів обох груп (дослідної та контрольної) не спостерігалося погіршення загального стану тварин. Зниження рухливості та апетиту - не відмічалося. 
Таблиця 2

Чутливість виділеної мікрофлори до антибактеріальних препаратів

\begin{tabular}{|c|c|c|c|}
\hline \multirow{2}{*}{ Антибактеріальні препарати } & \multicolumn{3}{|c|}{ Чутливість ізолятів } \\
\hline & Streptococcus spp. & Staphylococcus saprophyticus & Escherichia coli \\
\hline \multicolumn{4}{|l|}{ Пеніциліни } \\
\hline Ампіцилін & - & - & \pm \\
\hline Пеніцилін & + & + & - \\
\hline Амоксицилін & - & + & + \\
\hline Амоксицилін+ & - & - & - \\
\hline \multicolumn{4}{|l|}{ клавуланова кислота } \\
\hline Клоксацилін & - & \pm & \pm \\
\hline \multicolumn{4}{|l|}{ Аміноглікозиди } \\
\hline Гентаміцин & - & + & \pm \\
\hline Стрептоміцин & \pm & + & \pm \\
\hline Канаміцин & - & + & \pm \\
\hline Неоміцин & - & + & \pm \\
\hline Спектиноміцин & - & + & - \\
\hline \multicolumn{4}{|l|}{ Макроліди } \\
\hline Тілозин & + & + & - \\
\hline Азитроміцин & - & + & - \\
\hline \multicolumn{4}{|l|}{ Тетрациикліни } \\
\hline Доксицикліна гідрохлорид & \pm & + & \pm \\
\hline \multicolumn{4}{|l|}{ Похідні хінолону } \\
\hline Енрофлоксацин & \pm & \pm & + \\
\hline Офлоксацин & - & - & - \\
\hline Норфлоксацин & - & - & - \\
\hline Гатифлоксацин & - & - & - \\
\hline Ципрфлоксацин & - & + & + \\
\hline Левофлоксацин & - & + & + \\
\hline Марбофлоксацин & - & + & + \\
\hline \multicolumn{4}{|l|}{ Інша група } \\
\hline Цефтіофур гідрохлорид & + & + & + \\
\hline Лінкоміцин & + & + & + \\
\hline Хлорамфенікол & + & + & + \\
\hline Ко-Тримоксазол & + & + & - \\
\hline Сульфатіазол & + & + & - \\
\hline
\end{tabular}

При дослідженні корів та їх вимені, загального пригнічення тварин, пониження або відсутність апетиту, почастішання пульсу i дихання, підвищення температури тіла не встановлено. При тепловізорному дослідженні вимені корів встановлено, що термограма характеризувалася температурним градієнтом - у межах 35,7-36,0 ${ }^{\circ} \mathrm{C}$, строкатою кольоровою палітрою 3 переважанням теплих кольорів та вираженістю судинних тяжів.
Одержані дані дозволили зробити висновок, що корови дослідної групи, яким застосовували експериментальні препарати, одужали на 6-ту добу від початку проведення терапевтичних процедур. У корів контрольної групи одужання на цей час не встановлено (табл. 3). Таким чином, відмічено терапевтичну ефективність ветеринарних препаратів "Мастидев-Лінко", “Цефтіодеву $5 \%$ \%" та мазі “Дібуталястін” для лікування корів за клінічного маститу.

\section{Таблиця 3}

Ефективність різних схем лікування клінічного маститу корів ( $\mathrm{M} \pm \mathrm{m}, \mathrm{n}=12)$

\begin{tabular}{ccc}
\hline Показник & \multicolumn{2}{c}{ Група тварин } \\
\cline { 2 - 3 } & Дослідна & Контрольна \\
\hline Терапевтична ефективність, \% & 91,6 & 58,3 \\
Зникнення клінічних ознак, діб & $6,4 \pm 0,31^{* * *}$ & $9,8 \pm 0,45$ \\
\hline
\end{tabular}

Примітка: ${ }^{* * *}-\mathrm{P}<0,001$ відносно контролю

Відновлення якості молока в піддослідних корів у реакції з реактивом Profilac Reagent $\mathrm{N}$ наставало, в середньому, через 1,5-2,0 доби після зникнення клінічних ознак.

Крім того, врахувалося те, що мікроорганізми виділені в результаті дослідження, відносяться до зараз- них патогенів. Тому господарству рекомендовано звернути увагу на гігієну доїння:

- тварин, заражених заразними збудниками, слід доїти в останню чергу та ретельно дезінфікувати доїльні апарати. При можливості - відокремлювати заражених тварин та їх доїльне приладдя; 
- для роботи у доїльній залі використовувати одноразові гумові (латексні) рукавички;

- застосовувати перед- та післядоїльну обробку дійок вимені дезінфектантами (діпами);

- використовувати індивідуальні (одна серветка на одну корову) одноразові стерильні рушники (серветки) для обробки дійок вимені;

- періодично перевіряти в лабораторії дезінфікуючу здатність препаратів для обробки вимені та дезінфекції приладдя; використовувати тільки перевірені засоби;

- контролювати правильність приготування розчинів та проведення обробки вимені дезінфектантами (діпами): концентрація/експозиція/термін придатності/рівномірність нанесення розчину на дійки;

- вибраковувати тварин, які не піддаються лікуванню (хронічно хворих).

\section{Висновки}

1. Бактеріологічним дослідженнями молока, відібраних від корів, встановлена наявність Staphylococcus saprophyticus, Escherichia coli, $\beta$-гемолітичний Streptococcus spp.

2. Забруднене мікроорганізмами молоко є надзвичайно небезпечним для споживачів, оскільки призводить до виникнення захворювань або отруєнь різного ступеня тяжкості.

3. У результаті проведених досліджень щодо терапевтичної ефективності запропонованих ветеринарних препаратів у різних лікарських формах "Мастидев-Лінко”, “Цефтіодев 5 \%” та “Дібуталястін”, при застосуванні у корів голштинсько-фризької та чорнорябої породи, хворих на гнійно-катаральний мастит, встановлено 91,6 \% терапевтичну ефективність лікарських засобів.

Перспективи досліджень. В перспективі планується розробити протокол лікування гнійнокатарального маститу корів із препаратами "Мастидев-Лінко”, “Цефтіодев 5 \%” і “Дібуталястін” та завершити реєстраційні випробування препарату для зовнішнього застосування мазь “Дібуталястін”.

Відомості про конфлікт інтересів. Автори стверджують про відсутність конфлікту інтересів щодо їхнього вкладу та результатів досліджень.

\section{References}

Berezovskyi, A. V., Kharenko, M. I., \& Podvaliuk, D. V. (2018). Fiziolohiia ta patolohiia molochnoi zalozy $\mathrm{u}$ tvaryn [Physiology and pathology of the mammary gland in animals]. Kyiv: DIA (in Ukrainian).

Borodina, O. V., \& Dmytro, K. N. (2018). Bakterialna zabrudnenist diiok pid chas doinnia koriv na doilnomu maidanchyku [Bacterial contamination of teats during milking of cows on a milking parlor]. Naukovyi zhurnal "Tvarynnytstvo ta tekhnolohii kharchovykh produktiv", 271, 210-216 (in Ukrainian).

Jamali, H., Barkema, H. W., Jacques, M., LavalléeBourget, E. -M., Malouin, F., Saini, V., ... Dufour, S. (2018). Invited review: Incidence, risk factors, and effects of clinical mastitis recurrence in dairy cows. Journal of Dairy Science, 101(6), 4729-4746. doi: 10.3168/jds.2017-13730.

Kurtyak, B. M., Boyko, P. K., Boyko, O. P., Sobko, G. V., Romanovych, M. S., Pundyak, T. O., Mandygra, Yu. M., \& Gutyj, B. V. (2021). Autogenous vaccines are an effective means of controlling the epizootic process of mastitis in cows. Ukrainian Journal of Ecology, 11(3), 145-152. doi: 10.15421/2021_156.

Mohammed, Z. A., Mann, G. E., Robinson, R. S. (2019). Impact of endometritis on post-partum ovarian cyclicity in dairy cows. The Veterinary Journal, 248, 8-13. doi: 10.1016/j.tvj1.2019.03.008.

Paliy, A. P. (2017). Rol tekhnolohichnykh chynnykiv v oderzhanni vysokoiakisnoho moloka [The role of technological factors in obtaining high quality milk]. Visnyk Kharkivskoho natsionalnoho tekhnichnoho universytetu silskoho hospodarstva imeni Petra Vasylenka, 181, 94-97 (in Ukrainian).

Rokytskyi, P. F. (1973). Biolohicheskaia statystyka [Biological statistics]. Minsk: Vysheishaia shkola (in Russian).

Roman, L., Broshkov, M., Popova, I., Hierdieva, A., Sidashova, S., Bogach, N., Ulizko, S., Gutyj, B. (2020). Influence of ovarian follicular cysts on reproductive performance in the cattle of new Ukrainian red dairy breed. Ukrainian Journal of Ecology, 10(2), 426-434. URL: https://www.ujecology.com/abstract/ influence-of-ovarian-follicular-cysts-on-reproductiveperformance-in-the-cattle-of-new-ukrainian-red-dairybreed-54253.html.

Roman, L., Sidashova, S., Danchuk, O., Popova, I., Levchenko, A., Chornyi, V., Bobritska, O., Gutyj, B. (2020). Functional asymmetry in cattle ovaries and donor-recipients embryo. Ukrainian Journal of Ecology, 10(3), 139-146. doi: 10.15421/2020_147.

Roman, L., Sidashova, S., Popova, I., Stepanova, N., Chornyi, V., \& Gutyj, B. (2020). Clinical symptoms of damage to the lateral surface of the tibia of dairy cows of different phenotype in the conditions of industrial dairy production. Scientific Messenger of Lviv National University of Veterinary Medicine and Biotechnologies. Series: Veterinary sciences, 22(100), 3-10. doi: 10.32718/nvlvet10001.

Ruegg, P. L., \& Petersson-Wolfe, C. S. (2018). Mastitis in dairy cows. Veterinary Clinics: Food Animal Practice, 34(3), 1-12.

Saini, P., Singh, M., \& Kumar, P. (2019). Fungal endometritis in bovines. Open veterinary journal, 9(1), 94-98. doi: 10.4314/ovj.v9i1.16.

Shkromada, O., Skliar, O., Paliy, A., Ulko, L., Gerun, I., Naumenko, O., Ishchenko, K., Kysterna, O., Musiienko, O., \& Paliy, A. (2019). Development of measures to improve milk quality and safety during production. Eastern-European Journal of Enterprise Technologies, 3(11(99), 30-39. doi: 10.15587/17294061.2019.168762.

Singh, H., Brar, P. S., Honparkhe, M., Arora, A. K., \& Dhindsa, S. S. (2020). Subclinical endometritis in estrual buffaloes: diagnosis, prevalence and impact on reproductive performance. Tropical animal health and 
production, 52(1), 357-363. doi: 10.1007/s11250-01902022-w.

Stefanyk, V. Y., Stravsky, Ya. S., \& Kobyliukh, I. B. (2017). Supozytorii z vmistom nanochastynok Ferumu v korektsii antyoksydantnoho zakhystu orhanizmu koriv pislia otelu [Suppositories containing Iron nanoparticles in the correction of antioxidant protection of cows after calving]. Naukovyi visnyk Lvivskoho natsionalnoho universytetu veterynarnoi medytsyny ta biotekhnolohii imeni S.Z. Gzhytskoho, 19(82), 201204. URL: https://nvlvet.com.ua/index.php/ journal/article/view/1366 (in Ukrainian).
Thomas, V., Jong, A., Moyaert, H. et al. (2015). Antimicrobial susceptibility monitoring of mastitis pathogens isolated from acute cases of clinical mastitis in dairy cows across Europe: VetPath results. International journal of antimicrobial agents, 46(1), 13-20. doi: 10.1016/j.ijantimicag.2015.03.013.

Vos, P., Garrity, G., Jones, D. et al. (2011). Bergey's Manual of Systematic Bacteriology: The Firmicutes, 3. Springer Science \& Business Media. URL: https://www.springer.com/gp/book/9780387950419. 